\title{
Gastric Gastrointestinal Stromal Tumor with Bone Metastases - Case Report and Review of the Literature
}

\section{Gastrointestinální stromální nádor žaludku s diseminací do kostí - kazuistika a přehled literatury}

\author{
Şahin E. ${ }^{1}$, Yetişyiğit T. ${ }^{2}$, Öznur M. ${ }^{3}$, Elboğa U. ${ }^{4}$ \\ 'Department of Nuclear Medicine, Namık Kemal University Hospital, Tekirdağ, Turkey \\ ${ }^{2}$ Department of Medical Oncology, Namık Kemal University Hospital, Tekirdağ, Turkey \\ ${ }^{3}$ Department of Pathology, Namık Kemal University Hospital, Tekirdağ, Turkey \\ ${ }^{4}$ Department of Nuclear Medicine, Gaziantep University Hospital, Gaziantep, Turkey
}

\begin{abstract}
Summary
Gastrointestinal stromal tumors (GISTs) represent rather rare neoplasms. Most GISTs are benign; malignant tumors account for $20-30 \%$ of cases (overall, approximately $10-30 \%$ of GISTs exhibit malignant behavior). GISTs most commonly metastasize to the liver and abdominal cavity. Distant metastases to other sites, especially to the bones, are relatively rare. We report a case of a 62-year-old man with metastatic spread of GIST to skull, ribs and both sacroiliac joints manifesting six months after surgical resection of a gastric tumor. Although bone metastases from GISTs are rare and there are only a few reported cases in the literature, this case emphasizes that metastatic disease should always be considered in a patient with gastric GIST and suspicious bone lesions.
\end{abstract}

Key words

gastrointestinal stromal tumors - bone - metastasis

\section{Souhrn}

Gastrointestinální stromální nádory (GISTy) patří mezi vzácné diagnózy. Většina GISTů je považována za benigní, nicméně asi ve $20-30 \%$ případů se mưžeme setkat s maligním typem růstu ( celkově literatura udává rozmezí 10-30 \% př́ipadů). GISTy se nejčastěji šiří do jater a břišní dutiny. Jiné vzdálené metastázy, obzvlášt do kostí, jsou poměrně vzácné. Tato práce uvádí prípad 62letého muže s GISTem, u kterého po šesti měsících od resekce primárního tumoru žaludku došlo k metastatickému rozsevu nádoru do kostí lebečních, několika žeber a obou sakroilických kloubů. Přestože kostní diseminace GISTů je vzácná a literatura uvádí pouze několik podobných př́padů, autoři této práce zdůrazňují jejich význam v diferenciální diagnostice podezřelých kostních infiltrací.

\section{Klíčová slova}

gastrointestinální stromální nádory - kost - metastázy
The authors declare they have no potential conflicts of interest concerning drugs, products, or services used in the study.

Autoři deklarují, že v souvislosti s predmětem studie nemaji žádné komerční zájmy.

The Editorial Board declares that the manuscript met the ICMJE "uniform requirements" for biomedical papers.

Redakční rada potvrzuje, že rukopis práce splnil ICMJE kritéria pro publikace zasílané do biomedicínských časopisů.

$\Xi^{\circ}$

Ertan Şahin, MD

Department of Nuclear Medicine Namık Kemal University Hospital Tekirdağ

Turkey

e-mail:er_ahin@yahoo.com 


\section{Introduction}

Gastrointestinal stromal tumors (GISTs) are the most common mesenchymal neoplasms of the gastrointestinal tract. Most GISTs are benign; malignant tumors account for $20-30 \%$ of cases (instead of classifying lesions as either benign or malignant, current guidelines categorize GISTs as low-, intermediate-, and high-risk based on size and mitotic index; overall, approximately $10-30 \%$ of GISTs exhibit malignant behavior). Most frequently, GISTs arise from the stomach (60-70\%), small intestine (20-25\%), colon and rectum $(5 \%)$, or esophagus (<5\%). GISTs may also develop as primary tumors of the omentum, mesentery or retroperitoneum. Tumor resection is the treatment of choice for localized disease. Selective tyrosine kinase inhibitors (imatinib, sunitinib) are the standard therapy for metastatic or unresectable GISTs. The risk of recurrence is estimated from the mitotic index, size and the intial site of the tumor [1-3].

GISTs most commonly metastasize to the liver and abdominal cavity. Distant metastases to other sites, such as the bones or the lungs, are relatively rare [4-6]. Bone metastases have been reported, but their actual prevalence is unknown $[7,8]$. We report a case of bone metastases in a patient with gastric GIST supplemented by scintigraphic and radiologic findings.

\section{Case Report}

A 62-year-old male patient was referred to the hospital with abdominal pain, nausea and vomiting two years ago. A gastric endoscopy detected an ulcero-vegetan mass in his antrum (Fig. 1). A pathological examination of the biopsied specimens revealed a GIST. Abdominal computed tomography did not prove any other abnormality except for this gastric lesion. The patient subsequently underwent a partial gastric resection. By further histopathological analysis the tumor size concluded to be $4 \mathrm{~cm}$, the mitotic index was 7/50 High Power Field (HPF), the lesion belonged to moderate-risk group according to the $\mathrm{NIH}$ and AFIP criteria, with mixed cell type (epithelioid and spindle) and high cellu-

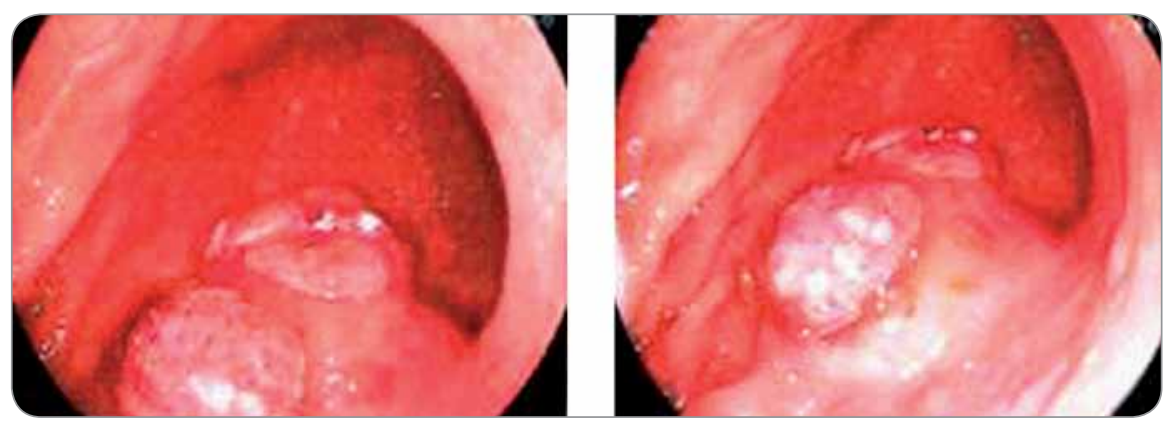

Fig. 1. An endoscopy showing antral gastric ulcerovegetan mass.

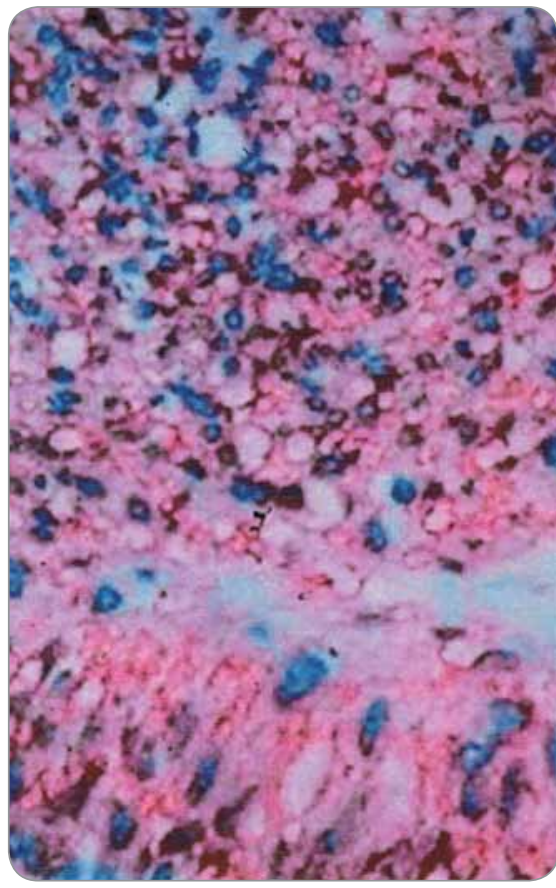

Fig. 2. Histopathological findings showed gastrointestinal stromal tumors (GISTs) (hematoxylin and eosin).

larity (Fig. 2). Using an immuno-histochemical staining the tumor was confirmed to overexpress c-kit (CD117) and CD34 protein. It should be noted, that this analysis was performed extramurally due to its unavailability at our institutehence there is no pathology documentation included. Following the resection, the patient had not received any adjuvant treatment. He was clinically stable and had no record of any untoward mediacal event during the follow-up period.

Six months after the operation he was presented to the hospital with complaints of weakness in the lower limbs. After physical examination, a lumbar MRI was performed, however, it yielded no specific results. Thus,

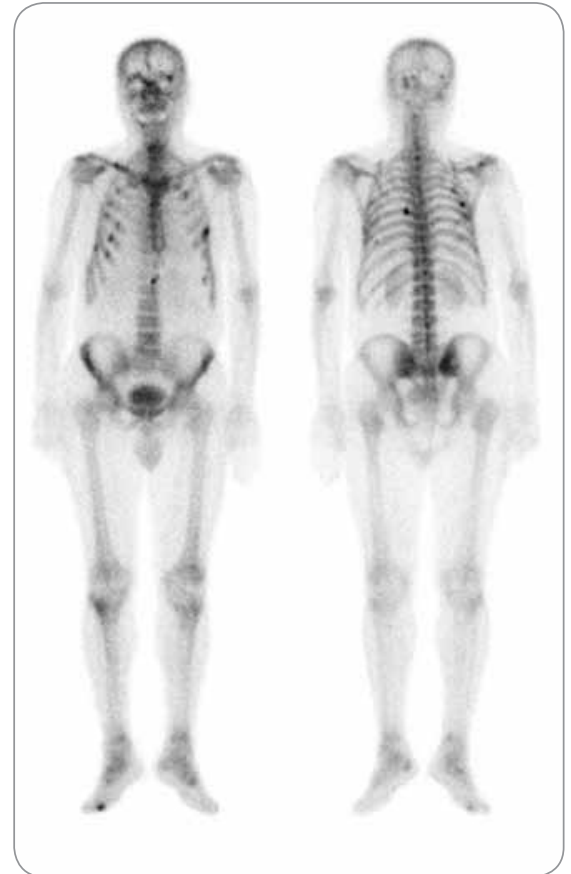

Fig. 3. GISTs metastatic bone lesions in bone scintigraphy.

bone scintigraphy was carried out for further clarification. It showed an increased tracer uptake localized in the skull, ribs and both sacroiliac joints (Fig. 3). Bone metastases of primary malignancy were suspected and the examination was supplemented by Fluorodeoxyglucose positron emission tomography-computed tomography (FDG PET/CT) scan for re-staging.

In accordance with bone scintigraphy, FDG PET/CT confirmed the hypermetabolic lesions in patient's ribs and sacroiliac joints (Fig. 4 A, B). The bone metastases showed increased FDG uptake with mean SUVmax: 4.3 (range 3.6-5.8). The overall character of the bone lesions appeared osteolytic with a small portion of mixed activity de- 

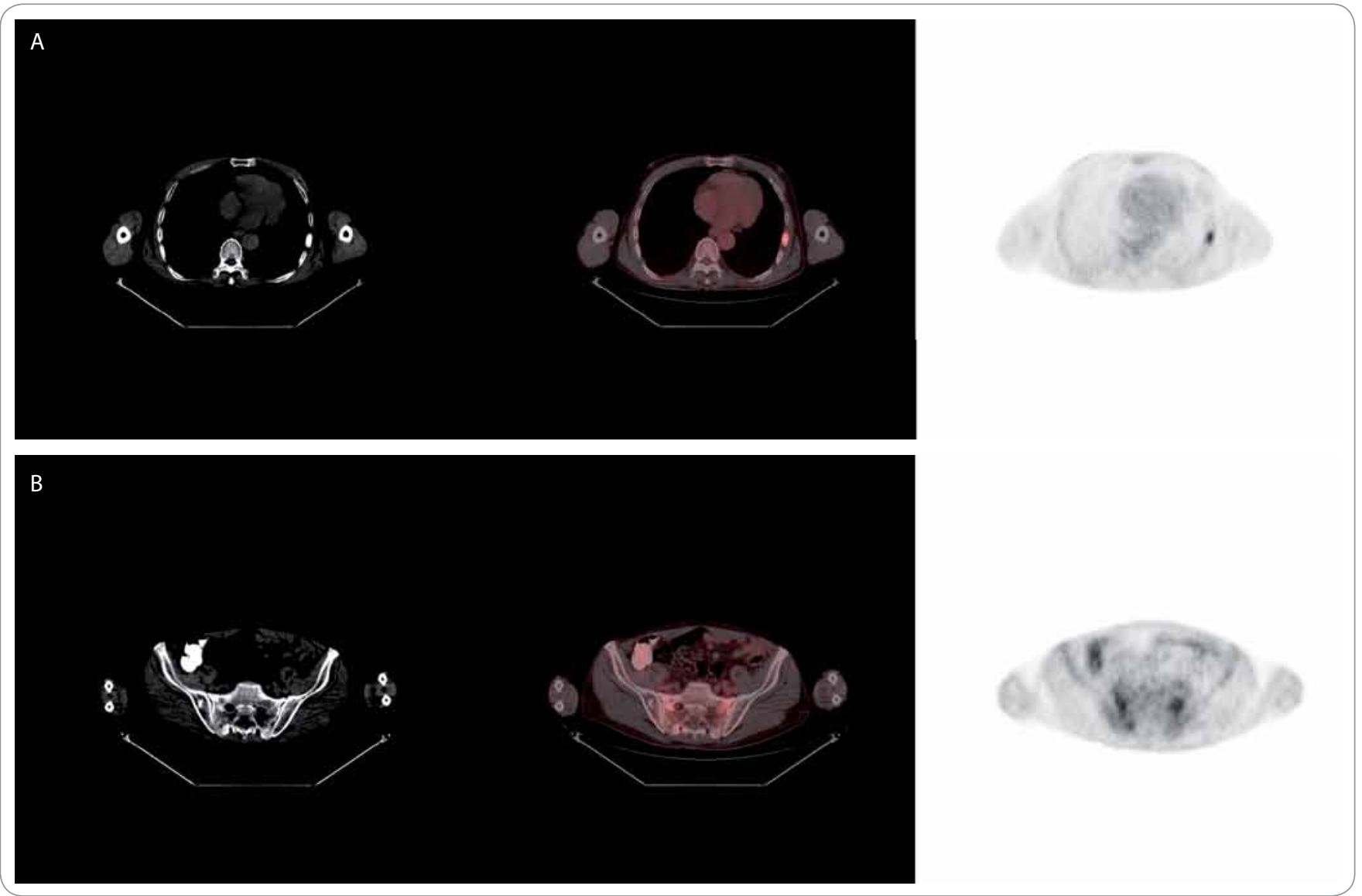

Fig. 4 A, B. GISTs metastatic bone lesions in PET/CT.

tected by CT scans). The patient was commenced on oral imatinib mesylate at a dose of $400 \mathrm{mg} / \mathrm{day}$. At the time of this report writing, he has still been receiving the treatment.

\section{Discussion}

Gastrointestinal stromal tumors (GISTs) are the most common mesenchymal tumors of the gastrointestinal tract. The term GIST was first coined by Mazur and Clark in 1983 to denote a heterogeneous group of non-epithelial neoplasms of the gastrointestinal tract. GISTs originate from interstitial cells of Cajal - intestinal pacemaker cells that arise from the muscularis propria of the gastrointestinal tract wall [9-11].

Approximately $90 \%$ of GISTs stain positively for the receptor tyrosine kinase, KIT (or CD117). Eighty-five percent of tumors harbor mutations in KIT and $5 \%$ in platelet-derived growth factor receptor alpha (PDGFRa) domain. In fact, targeting this receptor with a c-kit tyro- sine kinase inhibitor is of great clinical significance in the treatment of patients with unresectable or metastatic GIST, by reducing the tumor burden and improving survival rate [12-14].

Instead of classifying lesions as either benign or malignant, current guidelines categorize GISTs into low-, intermediate-, or high-risk group, depending on the tumor size and mitotic index. Prediction of the biological behavior of GIST at the time of the initial diagnosis may be difficult, however, large $(>5 \mathrm{~cm})$ tumors, high mitotic activity ( $>5$ mitoses per highpower field), high cellularity, the presence of necrosis, prominent nuclear pleomorphism, and certain activating c-kit mutations are predictive of malignant behavior $[1,14,15]$.

According to the largest epidemiological analysis to date, which included 1,458 recorded cases [16], or as reffered in a study by Miettinen and Lasota [17], GIST have a predilection to adults between $40-50$ years of age $[16,17]$.
The clinical presentation of GISTs is primarily dependent on the size. Small tumors $(\leq 2 \mathrm{~cm})$ are usually asymptomatic, often detected incidentally via endoscopy or at radiographic examination. The most common symptoms, though not specificaly GIST-related, include bleeding, upper abdominal pain, bloating or abdominal pressure and obstipation. Occasionaly, urgent abdominal complaints, such as massive gastrointestinal bleeding, perforation or bowel obstruction, may ocur [18].

Metastatic spread is a hallmark of a malignant behavior of the GIST. Overall, approximately $10-30 \%$ of GISTs exhibit malignant behavior. The most frequent site of occurrence is the stomach (60-70\%), small intestine (20-25\%), colon and rectum (5\%), or esophagus $(<5 \%)$. GISTs may also develop as primary tumors of the omentum, mesentery or retroperitoneum $[2,9]$.

Bone metastases in GISTs are rare, though nowadays, they are encountered 
far more frequently than in the past. This might be due to the advances in imaging techniques and the improvement of patients' overall survival rate following the introduction of tyrosine kinase inhibitors [19].

In the literature, there are only a few reported cases of patients with GIST metastases to the bone $[20,21]$. Bertulli et al reported 13 out of 278 patients (5\%) with GIST who developed bone metastases. In four patients this was the only metastasization site and the other nine cases were associated with another organ invasion [22]. In the study of Jati et al comprising 190 GIST patients, six (3.2\%) patients were reported to have bone metastases [23]. As rare as they appear, bone metastases are not an exception in patients with metastatic GIST, and any suspicious bone lesion should therefore be carefully evaluated, in order to prevent a serious bone event or other complications [23].

The detection of bone metastases in patients with GISTs is often based on a clinical presentation by itself (i.e. fractures or bone pain) or is an incidental finding on imaging evaluation. Hereby we emphasize the importance of bone metastases incidence for furher clinical practice despite the paradoxical paucity of available data on the sensitivity and specificity of bone scintigraphy and PET [19]. In this case, the bone metastases showed an increased FDG uptake (mean SUVmax: 4.3; range 3.6-5.8). The overall character of the bone lesions appeared osteolytic with a small portion of mixed activity detected by $\mathrm{CT}$ scans). The available literature does not provide consistent data on the treatment of bone metastases in GISTs. In several prospective trials, matinib mesylate has been reported to have activity against recurrent, metastatic, or unresectable GIST in $\mathbf{5 0} \%$ patients, whereas approximately 75-85\% patients achieved a stable disease. Imatinib mesylate was proven effective in the treatment of bone metastases of GIST [24]. The patient reffered in this work received oral imatinib mesylate at a dose of $400 \mathrm{mg} / \mathrm{day}$. At the time of this report writing, he has been receiving this treatment for 19 weeks. In comparison, Bertulli et al reported a 17-month $(3-40 \mathrm{~m})$ median survival in 13 patients with GIST metastatic to bones [22].

GISTs are not considered as a radiosensitive tumor [25], but radiotherapy can be considered as a palliative treatment option. The effect of biphosphonate administration to a patient with GIST bone lesions is unknown, yet, it is recommended in some of the works[19].

\section{Conclusion}

Although bone metastases of GISTs are relatively rare and there are only a few reported cases in the literature, this work gives emphasis on a careful evaluation of any suspicious bone lesions, especially in patients with high-grade (high-risk) GIST.

\section{References}

1. Nowain A, Bhakta H, Pais S et al. Gastrointestinal stroma tumors: clinical profile, pathogenesis, treatment strategies and prognosis. J Gastroenterol Hepatol 2005; 20(6) 818-824.

2. Miettinen M, Lasota J. Gastrointestinal stromal tumors: pathology and prognosis at different sites. Semin Diagn Pathol 2006; 23(2): 70-83.

3. Demetri GD, van Oosterom AT, Garrett CR et al. Efficacy and safety of sunitinib in patients with advanced gastronitestinal stromal tumour after failure of imatinib: a randomised controlled trial. Lancet 2006; 368(9544): 1329-1338.

4. Fletcher CD, Bermann JJ, Corless C et al. Diagnosis of gastrointestinal stromal tumours: a consensus approach. Hum Pathol 2002; 33(5): 459-465.

5. DeMatteo RP, Lewis JJ, Leung D et al. Two hundred gastrointestinal stromal tumors: recurrence patterns and prognostic factors for survival. Ann Surg 2000; 231(1) $51-58$

6. Miettinen M, Majidi M, Lasota J. Pathology and diagnostic criteria of gastrointestinal stromal tumors (GISTs): a review. Eur J Cancer 2002; 38 (Suppl 5): S39-S51.

7. Burkill GJ, Badran M, Al-Muderis O et al. Malignant gastrointestinal stromal tumor: distribution, imaging features, and pattern of metastatic spread. Radiology 2003; 226(2): 527-532.
8. Hersh MR, Choi J, Garrett C et al. Imaging gastrointestinal stromal tumors. Cancer Control 2004; 12(2): 111-115.

9. Ozan E, Oztekin O, Alacacioğlu A et al. Esophageal gastrointestinal stromal tumor with pulmonary and bone metastases. Diagn Interv Radiol 2010; 16(3): 217-220. 10. Mazur MT, Clark HB. Gastric stromal tumors. Reappraisal of histogenesis. Am J Surg Pathol 1983; 7(6): 507-519.

11. Kindblom LG, Remotti HE, Aldenborg F et al. Gastrointestinal pacemaker cell tumor (GIPACT): gastrointestinal stromal tumors show phenotypic characteristics of the interstitial cells of Cajal. Am J Pathol 1998; 152(5): 1259-1269.

12. Medeiros F, Corless CL, Duensing A et al. KIT-negative gastrointestinal stromal tumors: proof of concept and therapeutic implications. Am J Surg Pathol 2004; 28(7): 889-894.

13. Levy AD, Remotti HE, Thompson WM et al. Gastrointestinal stromal tumors: radiologic features with pathologic correlation. Radiographics 2003; 23(2): 283-304.

14. Joensuu H, Fletcher C, Dimitrijevic S et al. Management of malignant gastrointestinal stromal tumors. Lancet Oncol 2002; 3(11): 655-664.

15. Rubin BP. Gastrointestinal stromal tumours: an update. Histopathology 2006; 48(1): 83-96.

16. Tran T, Davila JA, El-Serag HB. The epidemiology of malignant gastrointestinal stromal tumors: an analysis of 1,458 cases from 1992 to 2000. Am J Gastroenterol 2005; 100(1): 162-168.

17. Miettinen M, Lasota J. Gastrointestinal stromal tumors (GISTs): definition, occurance, pathology, differential diagnosis and molecular genetics. Pol J Pathol 2003; 54(1): 3-24.

18. Bucher P, Villiger $P$, Egger JF et al. Management of gastrointestinal stromal tumors: from diagnosis to treatment. Swiss Med Wkly 2004; 134(11-12): 145-153.

19. Di Scioscio V, Greco L, Pallotti MC et al. Three cases of bone metastases in patients with gastrointestinal stromal tumors. Rare Tumors 2011; 3(2): e17. doi: 10.4081/rt.2011. e17.

20. Abuzakhm SM, Acre-Lara CE, Zhao W et al. Unusual metastases of gastrointestinal stromal tumor and genotypic correlates: case report and review of the literature. J Gastrointest Oncol 2011; 2(1): 45-49. doi: 10.3978/j. issn.2078-6891.2011.006

21. Miyake M, Takeda Y, Hasuike $Y$ et al. A case of metastatic gastrointestinal stromal tumor developing a resistance to STI571 (imatinib mesylate). Gan to Kagaku Ryoho 2004; 31(11): 1791-1794.

22. Bertulli R, Fumagalli E, Coco P et al. Unusual metastatic sites in gastrointestinal stromal tumor (GIST). J Clin Oncol 2009; 27 (15 Suppl): 10566.

23. Jati A, Tatlı S, Morgan JA et al. Imaging features of bone metastases in patients with gastrointestinal stromal tumors. Diagn Interv Radiol 2012; 18(4): 391-396. doi: 10.4261/1305-3825.DIR.5179-11.1.

24. Stamatakos M, Douzinas E, Stefanaki C et al. Gastrointestinal stromal tumor. World J Surg Oncol 2009; 7: 61. doi: 10.1186/1477-7819-7-61.

25. Blanke CD, Eisenberg BL, Heinrich MC. Gastrointestinal stromal tumors. Curr Treat Options Oncol 2001; 2(6): 485-491 